\title{
Analisis Tuturan Lara Pangkon dalam Upacara Temu Manten Masyarakat Kecamatan Ngantang Kabupaten Malang: Sebuah Kajian Pragmatik
}

\author{
${ }^{1}$ Trisnian Ifianti, ${ }^{2}$ Enis Fitriani \\ IKIP Budi Utomo, Malang, Indonesia \\ Email: ${ }^{1}$ trisnianifianti@budiutomomalang.ac.id \\ ²enisfitriani@budiutomomalang.ac.id

\section{Tersedia Online di \\ http://www.jurnal.unublitar.ac.id/i ndex.php/briliant}

\begin{tabular}{l}
\hline Sejarah Artikel \\
\hline Diterima pada 13 November 2020 \\
Disetujui pada 22 Februari 2021 \\
Dipublikasikan pada 28 Februari \\
2021 \\
Hal. $77-86$ \\
\hline
\end{tabular}

\section{Kata Kunci:} \\ Upacara temu manten; Lara \\ Pangkon; Masyarakat Kec. \\ Ngantang

\section{DOI:}

\begin{abstract}
Abstrak: Tujuan dari analisis tuturan Lara Pangkon upacara temu manten masyarakat Ngantang guna mengetahui makna eksplisit dan makna implisit tuturan. Penelitian deskriptif kualitatif ini menggunakan sumber data tuturan dalam Lara Pangkon, yakni data tulis dan data lisan. Pemerolehan data melalui observasi, wawancara, simak catat, dan dokumentasi. Data dianalisis dengan cara: (a) transkrip dan penerjemahan data, (b) klasifikasi data, (c) analisis data, dan (d) penarikan kesimpulan hasil penelitian. Hasil penelitian menunjukkan 15 tuturan yang dianalisis merupakan 7 tuturan eksplisit dan 8 tuturan implisit. Masyarakat Kecamatan Ngantang menggunakan tuturan bermakna implisit selain warisan nenek moyang juga merupakan petuah atau nasihat dalam kehidupan.
\end{abstract}

http://dx.doi.org/10.28926/briliant. v3i4.585

\section{PENDAHULUAN}

Indonesia kaya akan budaya yang memperkaya khasanah keberagaman budaya. Mulai dari lahir hingga meninggal dunia masyarakat Indonesia pasti akan mengalami berbagai macam upacara. Upacara bisa saja menjadi warisan tradisi turun temurun yang memiliki tujuan tertentu. Menurut Danandajaya (1997:1-2) tradisi merupakan budaya yang diwariskan turun temurun secara lisan atau contoh- contoh yang disertai isyarat sebagai alat bantu pengingat. Mereka mempunyai upacara- upacara adat yang biasanya dilakukan sebagai perwujudan rasa syukur kepada Tuhan yang Maha Esa. Ada juga tradisi upacara yang bertujuan menunjukan gambaran- gambaran nasihat dalam kehidupan. Upacara adat temu manten contoh nya. Masyarakat Ngantang mempunyai upacara adat temu manten yang sedikit berbeda dengan daerah lain. Dalam upacara adat temu manten akan ada sebuah fragmen atau layak nya darama satu babak yang di sebut Lara pangkon. Bagi masyarakat Ngantang, upacara Lara Pangkon ini tidak hanya upacara yang di laksanakan ketika temu manten. Tetapi upacara ini mengandung 
sarat makna dan simbol sebagai wakil dari pelaku upacara itu sendiri. Karena Tuturan dalam Lara pangkon tersebut menyampaikan pesan atau bentuk simbol tertentu. Tuturan yang terdapat dalam upacara Lara Pangkon adalah tuturan yang identik dengan simbol- simbol yang telah menjadi kesepakatan turun temurun dalam masyarakat Ngantang.

Berdasarkan observasi masyarakat Kecamatan Ngantang Kabupaten Malang merupakan masyarakat Jawa yang dalam hal bahasa telah mengalami percampuran dialek, hal ini dikarenakan letak geografis Ngantang yang berada di Malang bagian barat lebih dekat ke Kediri, Blitar, ataupun karena perkawinan campura antara penduduk asli setempat dengan orang luar pada jaman dulunya termasuk orang Jombang sehingga dialek bahasa yang di gunakan mengalami percampuran. Dalam berkomunikasi di kehidupan sehari-hari, masyarakat Ngantang menggunakan bahasa Jawa sebagai bahasa ibu. Begitu juga dalam kegiatan sosial, seperti bidang kesenian, adat istiadat, dan upacara keagamaan, masih digunakan secara aktif maupun pasif. Bahasa Jawa adalah sebagai alat dan maknanya mampu dipahami, artinya penutur dan petutur memiliki interaksi langsung dan dapat berbagi gambaran, situasi, nilai-nilai, tradisi, dan budaya. Namun seiring perkembangan jaman tentu tidak banyak orang khususnya generasi muda, dapat memahami makan yang terkandung dalam tradisi warisan nenek moyang yang turun temurun ini. Sehingga bisa saja tradisi tersebut akan hilang tergerus peradaban. Hal ini menarik untuk dikaji yaitu tuturan yang ada dalam upacara temu manten tersebut sehingga bisa dipahami makna tuturan nya dan bisa dipahami generasi muda serta menumbuhkan semangat generasi muda untuk berperan aktif dalm usaha pelestarian budaya ini.

Bahasa digunakan dalam konteks tempat dimana pengguna bahasa berada. Komunikasi akan terjadi karena ada pemahaman teks, konteks, dan pola atau struktur teks (Yule, 1996:1). Oleh karena itu dapat dipahami bahwa setiap bahasa memiliki tuturan yang terkait dengan konteks situasi. Dalam situasi tertentu bahasa yang digunakan akan merujuk pada makna yang dalm pemahamannya berhubungan dengan kegiatan tersebut. Merujuk pada hasil observasi yang dilakukan sebelumnya, dalam upacara temu manten masyarakat kecamatan Ngantang ada sebuah posesi Lara Pangkon yang tuturannya dibawakan oleh dua orang, seorang Pamasrah sebagai wakil dari pihak laki- laki dan seorang Panampi sebagai wakil pihak perempuan yang sulit dipahami jika hanya diterjemahkan secara gamblang. Hal ini dikarenakan adanya variasi bentuk, fungsi, dan makna berdasarkan penggunaan bahasa menurut konteks situasi penutur, tradisi, dan budaya setempat.

Tuturan tidak selalu mewakili langsung elemen makna unsur-unsurnya. Leech (dalam Wijana, 1996:10) menegaskan hal ini bahwa karena adanya bermacam-macam maksud yang disampaikan dalam pengujaran, selain harus memperhatikan aspek penutur dan mitra tutur, sebuah ujaran juga memperhatikan konteks dan tujuan tuturan, tuturan adalah bentuk tindakan, dan tuturan sebagai produk tindak verbal. Sementara itu, bahasa dipakai dalam konteks dimana bahasa itu berada. Masyarakat menggunakan bahasa karena memahami teks, konteks, dan pola atau struktur teks. Tuturan atau pembicaraan tidak terjadi begitu saja tanpa konteks situasi. Oleh karena itu, setiap maksud dapat dituturkan atau diungkapkan dalam berbagai macam atau modus tertentu. 
Pendapat Yule ini dapat dipahami bahwa tuturan yang memiliki makna yang harus dapat dimengerti sehingga dapat terjadi komunikasi yang baik. Tuturan tidak akan terjadi tanpa konteks situasi dan setiap maksud dapat dituturkan atau diungkapkan dengan berbagai modus tuturan. Dengan demikian, salah satu cara untuk memahami hal ini adalah melalui dimensi pragmatik. Menurut Yule (2006:3), Pragmatik adalah studi tentang makna yang dimaksud dan disampaikan penutur (penulis) dan dipahami oleh pendengar (pembaca). Termasuk pemahaman tentang apa yang dimaksudkan orang dalam suatu konteks khusus dan bagaimana konteks itu mempengaruhi ujaran. Diperlukan suatu strategi tentang bagaimana penutur mengatur ujaran sehingga hal tersebut bisa dipahami mitra turur, di mana, kapan dan dalam keadaan apa.

Meskipun dalam memahami makna ujaran, pragmatik tidak terlepas dari semantik, sebab keduanya bekerjasama secara komplementer, tetapi pada kenyataannya, kajian semantik tidaklah sama dengan pragmatik. Semantik memfokuskan kajian makna bahasa yang bersifat mandiri sesuai dengan bentuk bahasa yang tersurat. Sementara pragmatik lebih memfokuskan analisis makna yang ada kaitannya dengan konteks. Penelitian terdahulu yang dilakukan oleh Nadzir ( 2017) tentang analisis tindak tutur. Pada penelitian ini, objek penelitian yang dilakukan oleh Nadzir adalah tindak tutur dalam adat melamar pada masyarakat Kambowa, Kabupaten Buton Utara. Dengan hasil penelitian yang menunjukan adanya jenis- jenis tindak tutur dalam tuturan pada adat melamar masyarakat Kambowa yang terbagi dalam 5 kelompok, yaitu bentuk asertif, bentuk direktif, bentuk ekspresif, bentuk komisif, dan bentuk deklaratif. Sejalan dengan hasil penelitian yang di lakukan oleh Jamhar ( 2019) yang telah meneliti tuturan yang di gunakan dalam adat melamar masyarakat suku Kedang Omesuri kabupaten Lembata, dengan hasil penelitianyang menunjukkan bahwa ditemukan 17 tuturan dalam proses peminangan masyarakat Kedang Omesuri yang terdiri atas 10 tuturan bermakna eksplisit dan 7 tuturan bermakna implisit.

Uraian di atas membuat peneliti tertarik tidak hanya untuk mengkaji menggunakan pendekatan pragmatik agar dapat diketahui deskripsi bentuk dan deskrisi makna dalam tuturan Lara Pangkon pada upacara temu manten masyrakat kecamatan Ngantang kabupaten Malang tetapi juga untuk dikenalkan kepada generasi muda sebagai salah satu upaya pelestarian tradisi warisan turun temurun.

Pragmatik memiliki kaitan yang erat dengan semantik., makna sebuah tuturan didefinisikan dalam kaitannya dengan penutur. Tetapi semantic mendefinisakan makna adalah hanyalah sebagai identitas ujaran dalam suatu bahasa tertentu, terpisah dari situasi, penutur, dan mitra tutur

Hal ini sejalan dengan pemikiran Nurkamto (dalam Abdurrahman, 2011) yang menyatakan bahwa Penelitian semantik meneliti makna yang ada dari konteks fonetik. Sementara itu, pragmatik membahas makna dengan memperhatikan konteks wacana.. Oleh karena itu, dalam memahami ungkapan misalnya: "Sapi hitam itu sudah sangat gemuk", semantik hanya memperhatikan unsur- unsur bahasa dalam ujaran tersebut, yaitu kosa kata dan hubungan antar kosa kata itu; sedangkan pragmatik juga mengkaji siapa penuturnya, di mana, kapan, dan dalam situasi apa, di samping faktor-faktor bahasa yang lain. 
Dalam semantik, ungkapan di atas adalah merupakan ujaran informasi yang artinya bahwa memng sapi hitam tersebut sudah sangat gemuk; namun bagi kajian pragmatik kalimat tersebut dapat memiliki berbagai makna yaitu pemberitahuan bahwa sapi hitam itu sudah sangat gemuk, anjuran untuk dijual atau dipotong, atau hal lain memperhatikan konteks yang terjadi. Meskipun berbeda, namun terdapat keterkaitan yang erat antara pemahaman makna pragmatis dengan ungkapan semantik, artinya makna tuturan harus dipahami tidak hanya dari satu sisi, tetapi juga dari kedua sisi. Misalnya dari contoh di atas, orang tidak akan bisa memahami ungkapan "sapi hitam sangat gemuk", artinya jika tidak memahami arti dasarnya (semantik), artinya sapi tersebut dijual atau dipotong ( pragmatisme).

Ujaran atau Tuturan itu sendiri dalam KBBI (Depdiknas, 2005:1231), tuturan adalah sesuatu yang katakan; ucapan; ujaran. Tuturan adalah suatu ujaran dari seorang penutur terhadap mitra tutur ketika sedang berkomunikasi. Tuturan juga merupakan penyampaian perasaan atau maksud. Oleh karena itu, dapat disimpulkan bahwa tuturan adalah ungkapan perasaan atau kata-kata yang mempunyai arti/ maksud tertentu. Ada 2 hal yang berkaitan erat dengan ujaran atau tuturan

a. Peristiwa Tutur

Chaer dan Agustina (2004: 47) mengatakan bahwa peristiwa tutur mengacu pada proses interaksi bahasa dalam satu atau lebih ujaran, yang melibatkan dua pihak, penutur dan mitra wicara, memiliki topik tuturan utama pada waktu, tempat dan situasi tertentu.. Komunikasi antara seorang penjual dan pembeli di pasar pada waktu tertentu dengan menggunakan bahasa sebagai alat komunikasinya adalah sebuah peristiwa tutur. Hal yang sama juga terjadi di kampus, di pos ronda, di warung dan sebagainya.

b. Konteks Tuturan

Dalam penelitian bahasa, semua aspek fisik atau lingkungan sosial terkait dengan ucapan. Konteks fisik biasanya disebut koteks (teks umum), dan konteks lingkungan sosial disebut konteks. Dalam pragmatik, konteks adalah semua latar belakang pengetahuan yang dibagikan oleh penutur dan mitra tutur saat tuturan terjadi.

Dell Hymes (dalam Chaer, 2010:48) menjelaskan konteks meliputi 8 (delapan) dimensi, yaitu: 1) setting and scene, adalah waktu dan tempat tuturan, sementara itu scene adalah pada situasi dan kondisi psikologis pembicara. Apabila dua hal ini berbeda dalam suatu tuturan yang berbeda tentu akan menimbulkan penggunaan variasi bahasa berbeda pula. 2) participants adalah pelaku dalam tuturan, bisa pembicara dan pendengar, penyapa dan pesapa, atau pengirim dan penerima (pesan). 3) ends adalah maksud dan tujuan ujaran tersebut. 4) act sequence yaitu bentuk dan isi ujaran. Meliputi apa dan bagaimana ujaran digunakan dan hubungannya antara ujaran dengan topik pembicaraan. 5) key adalah nada dan cara ujaran tersebut disampaikan. Hal ini dapat juga ditunjukan dengan gerak tubuh dan isyarat. 6) instrumentalities adalah moda atau model bahasa yang digunakan, seperti lisan, tertulis, melalui telegram atau telepon. Hal ini juga mengacu pada kode ujaran yang digunakan, seperti bahasa, dialek, ragam atau register. 7) norm of interaction and interpretation adalah norma atau aturanaturan dalam interaktif. Misalnya bagaimana cara interupsi, bertanya yang 
mengacu pada norma pemahaman terhadap ujaran dari mitra bicara. 8). genre yaitu jenis bentuk penyampaian seperti narasi, puisi, pepatah, doa, dan lain sebagainya.

Makna dalam peristiwa tutur dapat dipahami berbeda apabila tidak terjadi kesepahaman dalm berkomunikasi. Makna ialah hubungan antara bahasa dengan masyarakat yang telah disepakati bersama oleh pengguna bahasa sehingga terjadi kesepahaman. Sementara itu Lyons (1981:136) mengatakan bahwa makna adalah maksud tertentu, yakni ide atau konsep yang berasal dari pikiran manusia dan diutarakan melalui bahasa.

KBBI (dalam Pateda, 2001:82) kata makna didefinisikan sebagai konsep gagasan, atau ide yang diwujudkan dalam bentuk ujaran dan tulisan, verbal atau non verbal. Lain lagi dengan Larson (1984: 34) yang menyatakan bahwa makna tidak ditampilkan tetapi itu adalah bagian dari pembicaraan atau maksud yang ingin disampaikan penutur kepada mitra tutur. Di dalam proses memahami makna ini, penanggap tutur seringkali harus berusaha keras untuk bisa memahami tafsiran yang tepat antara lain dengan melalui pembayangan atau penjelasan. Penanggap tutur harus mengetahui hal tertentu yang menjadi acuan, situasi dan konteks.

Pengetahuan konteks akan sangat membantu penanggap tutur untuk mendapat tafsiran yang tepat. Larson juga membagi perwujudan makna kedalam dua jenis yakni: Makna Eksplisit; Menurut Larson, makna eksplisit yaitu penjelasan unsur gramatikal yang jelas atau dengan kata lain makna eksplisit merupakan makna sebenarnya yang diutarakan secara gamblang, tegas dan berterus terang sehingga pendengar dapat dengan jelas mengerti maksud dan tujuan dari pernyataan yang diutarakan oleh penutur. Makna Implisit; Masih menurut Larson, "Makna implisit adalah makna yang tidak diucapkan tetapi merupakan bagian dari pembicaraan atau tujuan yang ingin disampaikan oleh pembicara". Untuk mengetahui makna implisit, pendengar atau pembaca harus melakukan interpretasi. Pembaca atau pendengar ini harus mengetahui beberapa hal seperti rujukan, keadaan, dan konteks. Pengetahuan kontekstual akan membantu pembaca untuk menemukan intepretasi yang tepat. Teori Larson inilah yang dijadikan landasan penelitian ini dalam menganalisis tuturan Lara Pangkon dalam upacara temu manten masyarakat Ngantang.

\section{METODE}

Penelitian ini menggunakan metode deskriptif kualitatif, metode ini merupakan prosedur pemecahan masalah yang diselidiki dengan menggambarkan objek penelitian berdasarkan fakta yang ada. Penelitian deskriptif kualitatif adalah prosedur penelitian data deskriptif yang berupa kata-kata tertulis atau lisan dari masyarakat dan perilaku yang dapat diamati sebagai hasil dari penelitian tersebut (Moleong, 2008:4). Penelitian ini menganalisa tuturan Lara Pangkon dalam upacara temu manten masyarakat kecamatan Ngantang dan dengan deskripsi tertulis untuk mendeskripsikan dan menjelaskan data yang diperoleh yaitu data tuturan Lara Pangkon, kemudian memberikan analisa dan kesimpulan secara umum berdasarkan masalah penelitian. Betempat di Kecamatan Ngantang, Kabupaten Malang penelitian ini berlangsung sema kurang lebih 9 bulan terhitung 
sejak penyusunan rancangan penelitian sampai tahap penulisan laporan. Bersumber dari sumber tertulis seperti buku atau artikel hasil penelitian pada analisa tuturan dalm sebuah upacara juga menggunakan sumber data lisan yaitu data yang diperoleh dari narasumber atau tokoh pelaku Lara Pangkon, yaitu 2 orang yang biasa melakonkan posesi Lara Pangkon baik berperan sebagai Pamasrah dan Panampi. Teknik pengumpulan data dalam penelitian ini adalah melalui observasi terlebih dahulu yakni pengmbilan data secara langsung dengan menggunakan mata tanpa ada ada bantuan alat, peneliti mengamati langsung posesi Lara Pangkon yang ada dalam sebuah upacara temu manten. Kemudian wawancara dilakukan terhadap narasumber di Kecamatan Ngantang, dengan merekam, menyimak dan mencatat semua informasi yang berkaitan dengan tradisi Lara Pnagkon dalam upacara temu manten. Peneliti juga mendokumentasikan semua hal yang berkaitan dengan pengambilan data.

Teknik pengolahan data yang telah didapatkan kemudian diolah atau dianalisis berdasarkan makna (makna eksplisist dan makna implisit) dengan cara antara lain sebagai berikut: (1) Transkip data: tuturan dalam proses peminangan yang telah direkam selanjutnya ditranskip kedalam bahasa tulis sesuai bahasa aslinya. (2) Terjemahan: tuturan yang telah ditranskipkan tersebut selanjutnya diterjemahkan kedalam Bahasa Indonesia yang sesuai dengan kaidah. (3) Klasifikasi data: tuturan yang telah diterjemahkan dalam Bahasa Indonesia kemudian di klasifikasikan berdasarkan teori Larson. (4) Analisis: data kemudian dianalis, yakni mendeskripsikan bentuk dan mendeskripsikan makna tuturan Lara Pangkon dalam upacara temu manten masyarakat Ngantang (5) Menyimpulkan hasil penelitian.

\section{HASIL}

Lara Pangkon merupakan sebuah posesi dalam upacara temua manten yang menggambarkan sebelum mempelai pria bertemu dengan mempelai wanita, terlebih dulu diarak mengelilingi desa, diikuti pengiring dan seorang yang menggendong replika ayam jago dari kayu dihias sedemikian rupa bercucuk uang atau perhiasan, berselimut kain warna- warni. Para pengiring membawa perlengkapan, berupa 2 buah kembar mayang, 2 pucuk tombak, pelarang, jodhang, bubak kawah( rangkaian alat- alat dapur), setandan kelapa, aneka kue dan makanan.Lara pangkon sebagai akronim dari lara sadurunge kelakon. Lara pangkon diperagakan oleh 2, Pamasrah dan Panampi, dimana seorang Pamasrah membawa jago-jagoan sebagai simbol mempelai pria yang dihias sedemikian rupa, dan dilengkapi sebuah bokor berisi beras kuning.

Peragaan itu diawali dengan suara ayam jantan/ jago dan riuh rendah pengiring nya. Salah seorang pelaku yang disebut Pamasrah menggendong jagojagoan dan para pengiring membawa ubo rampe temu manten penuh suka cita. Sementara itu datang seorang pelaku lainnya yang disebut Panampi menyambutnya. Adapun beberapa data yang ditemukan secara garis besar terdapat 2 bagian dalam Lara Pangkon yaitu Pambuka dan Paneges. Pada tahap Pambuka, Pamasrah selaku wakil dari pihak pengantin perempuan mendatang rumah pihak pegantin perempuan yang di yakini sebagai pasangan dari pengantin laki- laki. Pamasrah dengan membawa ayam jago terbuat dari kayu sebagai simbol dari pengantin laki- laki diikuti banyak oarang sebagai pengiring. Pada bagian ini 
tuturan nya berisikan perkenalan dan penjelasan keberadaan si Jago (simbol penganti laki- laki). Tuturan ini disampaikan dengan tujuan memberitahukan bahwa ada Jago (pengantin laki- laki) yang sedang mencari pasangan. Diceritaan dalam tuturan itu asal usul si jago, kehebatan- kehebatan si jago dan apa saja yang dibawa dalam pengembaraannya mencari pasangan.

Yang kedua adalah tahap Paneges, pada tahap Peneges ini mempunyai makna yaitu bagian dimana setelah di kenalkan dan di jelaskan kehebatan si Jago (pengantin laki- laki) Panampi sebagai wakil keluarga pengantin perempuan benar- benar ingin memiliki si jago( simbol pengantin laki- laki). Sehingga setelah melakukan perebutan di gambarkan dengan pertunjukan pencak silat pendek, Pamasarah menegaskan kembali bahwa si jago ini memang layak dimiliki pihak pengantin putri dengan syarat dan ketentuannya. Pada bagian ini tuturan nya menegaskan syarat- syarat atau hal- hal penting yang harus di perhatikan juga petuah- petuah dalam memeliharanya sehingga bisa tetap hidup.

\section{PEMBAHASAN}

Bentuk dan Makna Tuturan Lara Pangkon dala upacara temu manten masyarkat kecamatan Ngantang kabupaten Malang. Pada tahap ini bentuk-bentuk tuturan yang ada di dalam tuturan Lara Pangkon dianalisis berdasarkan teori Larson (1984) tentang makna eksplisit dan makna implisit.

\section{Makna Eksplisit}

Makna eksplisit merupakan rangkaian makna dengan unsur gramatikal yang jelas atau dengan kata lain makna eksplisit adalah makna sebenarnya yang diujarkan secara lugas, tegas dan berterus terang sehingga pendengar dapat dengan jelas mengerti apa makna dan tujuan dari ujaran si penutur (Larson 1984: 34). Ada beberapa tuturan eksplisit dalam tuturan Lara Pangkon dalam upacara temu manten masyarakat Kecamatan Ngantang baik dalam tahap Pambuka maupun dalam tahap Paneges adalah sebagai berikut.

a. "Lha sampeyan niki saking pundi pinangkane?"

Tuturan ini mempunyai denotasi yaitu bertanya baik- baik. Maksud dari tuturan ini adalah menanyakan dari mana asal rombongan jagoan/ pengantin pria.

Cara penyampaiannya lugas dan biasa dilakukan kepada orang yang ditemui, secara baik dan cerminan budaya Jawa yang ramah.

b. "Lha ingkang sampeyan beto niku napa, Dhik?"

Tuturan tersebut merupakan bentuk tuturan yang mempunyai maksud bertanya apa yang dibawa. Hal ini sebagai bentuk ungkapan apabila mengetahui orang membawa sesuatu tetapi tidak tahu apa yang dibawa.

c. "Lha kok jago sampeyan mboten saged kluruk, Dhik?"

Kata kluruk berarti berkokok yang mana ketika mengetahui yang dibawa adlah ayam jago tetapi ayam tersebut diam saja tidak berkokok. Hal ini lumrah karena memang ketika ayam jago di pegang tentu akan berkokok atau mengeluarkan suara tetapi ini tidak. Sehingga menimbulkan pertanyaan.

d. "Lha nopo tebusane?"

Ungkapan nopo tebusane memiliki makna bertanya akan syarat untuk mendapat sesuatu. Ujaran ini memang memiliki makna bertanya apa tebusan yang harus diberikan apabila ingin mendapatkan sesuatu.

e. "Lha gemrudug neng wingking sampeyan niku sinten, Dhik?" 
Kata gembrudug berarti berbondong- bondong yang artinya beramairamai mengantarkan jago/ pengantin laki- laki karena memang datangnya jago/ pengantin laki- laki diikuti pengiring yang membawa segala sesuatu yang dibutuhkan dalam pernikahan.

f. "Wah, nek ngaten empun ngerti sedoyo kulo, jelenterehe"

Tuturan ini mempunyai makna bahwa telah terjadi pengertian atau pehaman atas apa saja yang dijelaskan oleh pihak pengantin laki- laki dalam membawakan Lara Pangkon. Kata "jelenterehe" bermakna penjelasan dari keseluruhan yang diujarkan dan dipahami.

\section{Makna Implisit}

Dalam memahami makna implisit suatu ujaran dibutuh interpretasi makna dari pendengar atau pembaca. Pembaca atau pendengar ini harus mengetahui beberapa hal seperti rujukan, keadaan, dan konteks. Pengetahuan kontekstual dapat membantu pembaca untuk menemukan intepretasi yang tepat. Berikut analisis tuturan yang memiliki makna implisist dalam tuturan Lara Pangkon pada upacara temu manten masyarakat kecamatan Ngantang.

a. "Putih ing wetan panggonane, manuke kuntul, gunungane kapur, segorone santen, kembange kembang cempaka, kuthone sloko, sing mengku Bethoro Guru, manjing neng ati suci."

Tuturan ini biasanya dituturkan pada saat Panampi menanyakan maksud mengapa bulu- bulu jago sangat menarik hati , berwarn- warni dengan memiliki 4 warna.Tuturan ini memiliki makna bahwa membangun rumah tangga atau pernikahan hendaknya didasari niat yang tulus suci. Kata "putih" merupakan simbol kesucian yang memiliki perluasan makna niat tulus suci.

b. "Abang ing kidul panggonane, manuke wulung, segorone getih, gunungane geni, kembange wurawaribang, kuthane tembogo, sing mengku Bethoro Bromo, manjing nduk durgomongso."

Makna dari tuturan ini adalah kpernikahan yang dibangun didasari rasa berani, bertanggung jawab atas apapun cobaan nantinya. Kata "abang" memiliki makna berani dalam menghadapi baik dan buruk nya berumah tangga juga di paparkan dalam tuturan ini.

c. "Kuning neng kulon panggonane, manuke podang, segorone madu, gunungane welirang, kembange kenikir, kuthone kuningan, sing mengku Bethoro Komojoyo, manjinge nduk kebrahen"

Tuturan ini artinya adalah penggambaran bahawa dalam pernikahan tentau akan ada manis dan bahagia. Kata kuning dan madu adalah simbol kebahagiaan, kekayaan dan cinta kasih yang hendaknya diusahakan bersama.

d. "Ireng neng lor panggonane, manuke gagak, segorone nilo, gunungane areng, kembange menteleng, kuthone wesi, sing mengku Bethoro Wisnu, manjing nduk sipat kelanggengen.

Tuturan ini memiliki makna bahwa pernikahan pun akan mengalami yang namanya kesedihan bahkan mungkin juga ketidak langgenggan, dalam arti di pisahkan oleh kematian. Kata "sipat kelanggengan" memiliki makna keabadian. Diharapkan pernikahan akan langgeng meskipun di timpa berbagai godaan dan kesedihan sampai akhir hayat.

e. "Sega putih niku wis suci, nek wis suci kudu sing ati-ati, supoyo luwihluwih sing disandang lan dipangan." 
Tuturan ini merupakan jawaban dari tuturan "Putih ing wetan panggonane, manuke kuntul, gunungane kapur, segorone santen, kembange kembang cempaka, kuthone sloko, sing mengku Bethoro Guru, manjing neng ati suci.". Setelah memiliki niat tulus suci membangun rumah tangga maka diharapkan kedua pengantin dapat berhati- hati dalam merawat pernikahannya. Baik dalam hal mencari penghidupan sehingga bisa mendapatkan keberkahan.

f. "Wadhah kawah condrodimuko, isine durga pangongso-ongso."

Tuturan wadah kawah condrodimuko berarti tempat menempa kemampuan diri. Artinya pernikahan adala tempat mempa kemampuan diri yang sesungguhnay. Keammpuan untuk mengasihi pasangan kita, kemampuan untuk merawat, mendidik anak- anak kita, dan juga temapt untuk menempa kemampuan kita mendapatkan penghidupan yang lebih baik. sing siji wujud."

g. "Sing ngombeni dulur papat lima badan, sing papat manjing nduk keblat,

Tuturan "Sing ngombeni dulur papat lima badan, sing papat manjing nduk kiblat sing siji wujud". Tuturan ini memiliki makna yang luas dalam konteks mencari penghidupan dalam pernikahan. Kata sing ngobeni artinya kehidupan, dulur papat lima badan artinya dari ke 4 penjjuru mata angina. Maknanya bahwa segala hal yang berkenaan dengan penghidupan dalam berumah tangga bisa dicari dari segala penjuru. Sehingga hendaknya dalam pernikahan tidak boleh ada perasaan takut akan tidak mendapatkan penghidupan.

h. "Dalem madigondo, bantal piwarah, kemul pitutur, dene kurungane lair lan batin, mudune jengkar guling kursi gading."

Tuturan ini memiliki makna bahwa dalam pernikahan hendaknya selalu mendengarkan nasehat dan petuah orang tua. Hal ini diyakini dapat menjadikan pernikahan bisa langgeng dan bahagia lahir dan batin.

\section{KESIMPULAN}

Dalam tuturan Lara Pangkon pada upacara temu manten masyarakat kecamatan Ngantang kabupaten Malang terdapat dua tahapan yaitu Pambuka dan Paneges dan memiliki diantaranya 15 tuturan yang terdiri atas 7 tuturan bermakna eksplisit dan 8 tuturan bermakna implisit. Masyarakat kecamatan Ngantangi menggunakan tuturan bermakna implisit dalam proses peminangan karena merupakan tuturan turunan nenek moyang dan juga merupakan sebuah ekspresi seni dalam berbahasa atau berkomunikasi.

\section{SARAN}

Disarankan untuk penelitian selanjutnya untuk melakukan kajian yang sama, namun dengan menggunakan pendekatan yang berbeda pada tuturan Lara Pangkon dalam upacara temu manten di tempat yang berbeda guna melengkapi kekurangan tulisan ini sehingga bisa di komparasi hasil temuan dan analisis sebagai bahan pengetahuan untuk generasi muda sehingga para geerasi muda bisa ikut serta dalam usaha pelestarian warisan tradisi budaya yang sudah turun temurun dari nenek moyang. 


\section{DAFTAR RUJUKAN}

Addurrahman. 2011. Pragmatik; Konsep Dasar Memahami Konteks Tuturan. (Online),(www.researchgate.net/publication/283403378_pragmatik_kons ep_d asar_memahami_konteks_tuturan, diakses tanggal 15 Juli 2020).

Chaer, Abdul dan Agustina, Leonie. 2004. Sosiolinguistik Perkenalan Awal. Jakarta: Rineka Cipta.

Chaer, Abdul. 2010. Kesantunan Berbahasa. Jakarta: Rineka Cipta

Danandjaja, James. 1984. Folklor Indonesia. JakartaPustaka Grafiti Press

Jamhar. Ramadhan. 2019. Analisa Tuturan Upacara Adat Peminanagan Masyarakat Suku Kedang Omesuri Kabupaten Lembata (Sebuah Kajian Pragmatik) (online)

(http://ejournal.umbandung.ac.id/index.php/RASI/article/view/45) diakses tanggal 6 Agustus 2020

Larson, L. Mildred. 1984. Meaning Based Translation: A Guide to CrossLangugae Equivalence. Lanham: University Press of America

Lyons, John. 1981. Language and Linguistic. Cambridge: Cambridge University Press.

Moleong, Lexy J, 2008. Metodologi Penelitian Kualitatif. Bandung: Remaja Rosda Karya.

Nadar, F.X. 2009. Pragmatik dan Penelitian Pragmatik. Yogyakarta: Graha Ilmu.

Nadzir, Muhamad. 2017. Tindak Tutur dalam Adat Melamar pada Masyarakat Kambowa Kabupaten Buton Utara. Jurnal Bastra, 1(4): 1-20, (online), (http://ojs.uho.ac.id/index.php/BASTRA/article/view/2341)

Pateda, Mansoer. 2001. Semantik Leksikal. Jakarta: Rineka Cipta.

Wijana, I Dewa Putu. 1996. Dasar-dasar Pragmatik. Yogyakarta: Andi Offset.

Yule, George. 1996. Pragmatics. Oxford: Oxford University Press.

Yule, George. 2006. Pragmatik. Yogyakarta: Pustaka Pelajar.

Departemen Pendidikan Nasional. 2005. Kamus Besar Bahasa Indonesia (edisi 3). Jakarta: Balai Pustaka.

Yuniseffendri. Modul 1: Pragmatik Selayang Pandang. (Online), (repository.ut.ac.id/4754/1/PBIN4212-M1.pdf, diakses tanggal 29 Agustus 2020

Selayang Pandang Kabuten Malang: (Online), https://sippa.ciptakarya.pu.go.id/sippa_online/ws_file/dokumen/rpi2jm/, diakses tanggal 25 Juli 2020 